Research Paper

\title{
Sex-Steroid Regulation of Relaxin Receptor Isoforms (RXFPI \& RXFP2) Expression in the Patellar Tendon and Lateral Collateral Ligament of Female WKY Rats
}

\author{
Firouzeh Dehghan ${ }^{1}$, Sekaran Muniandy ${ }^{2}$, Ashril Yusof ${ }^{3}$ and Naguib Salleh ${ }^{1}$ \\ 1. Department of Physiology, Faculty of Medicine, University of Malaya, 50603 Kuala Lumpur, Malaysia; \\ 2. Department of Molecular Medicine, Faculty of Medicine, University of Malaya, 50603 Kuala Lumpur, Malaysia; \\ 3. Department of Physiology, Sport Center, University of Malaya, 50603 Kuala Lumpur, Malaysia.
}

\begin{abstract}
$\bowtie$ Corresponding author: E-mail: naguib.salleh@yahoo.com.my Tel: 0060379677532 Fax: 0060379674775.
(c) Ivyspring International Publisher. This is an open-access article distributed under the terms of the Creative Commons License (http://creativecommons.org/
\end{abstract} licenses/by-nc-nd/3.0/). Reproduction is permitted for personal, noncommercial use, provided that the article is in whole, unmodified, and properly cited.

Received: 2013.03.20; Accepted: 2013.II.25; Published: 2014.0I.09

\begin{abstract}
The incidence of non-contact knee injury was found higher in female than in male and is related to the phases of the menstrual cycle. This raised the possibility that female sex-steroids are involved in the mechanism underlying this injury via affecting the expression of the receptors for relaxin, a peptide hormone known to modulate ligament laxity. Therefore, this study aims to investigate the effect of sex-steroids on relaxin receptor isoforms (RXFPI \& RXFP2) expression in the ligaments and tendons of the knee. Methods: Ovariectomized adult female WKY rats were treated with different doses of estrogen $(0.2,2,20 \mu \mathrm{g} / \mathrm{kg}$ ), progesterone $(4 \mathrm{mg})$ and testosterone (I 25 \& $250 \mu \mathrm{g} / \mathrm{kg}$ ) for three consecutive days. At the end of the treatment, the animals were sacrificed and the patellar tendon and lateral collateral ligament were harvested for mRNA and protein expression analyses by Real Time PCR and Western blotting respectively. Results: RXFPI, the main isoform expressed in these knee structures and RXFP2 showed a dose-dependent increase in expression with estrogen. Progesterone treatment resulted in an increase while testosterone caused a dose-dependent decrease in the mRNA and protein expression of both relaxin receptor isoforms. Discussion: Progesterone and high dose estrogen up-regulate while testosterone down-regulates RXFPI and RXFP2 expression in the patellar tendon and lateral collateral ligament of rat's knee. Conclusion: Relaxin receptor isoforms up-regulation by progesterone and high dose estrogen could provide the basis for the reported increase in knee laxity while down-regulation of these receptor isoforms by testosterone could explain low incidence of non-contact knee injury in male.
\end{abstract}

Key words: RXFP1, RXFP2, sex-steroids, patellar tendon, collateral ligaments.

\section{Introduction}

Relaxin which consist of relaxin-1, -2 and -3 and insulin-like peptides (INSL3, 4, 5 and 6) [1] is a polypeptide hormone that possesses structural similarity to insulin and is primarily synthesized by the corpus luteum and placenta [2]. Relaxin binds to and activates G-protein-coupled receptors (GPCRs): RXFP1(LGR7) and RXFP2(LGR8) [3]. Human relaxins $\mathrm{H} 1$ and $\mathrm{H} 2$ activate both RXFP1 and RXFP2 [4], while rat relaxin1 binds weakly to RXFP2 [5]. Relaxin H3 binds selectively to RXFP1 as well as RXFP3 (GPCR135) and RXFP4 (GPCR142) [6]. RXFP1 and RXFP2 are the two main relaxin receptor isoforms [7].

Relaxin activity has been reported in both pregnant and non-pregnant female primates and non-primate vertebrates $[8,9]$. In primates, ovarian relaxin is not required for successful term pregnancy 
[8] however is required to maintain pregnancy in rats and pigs [10]. During pregnancy in mice, relaxin is involved in transformation of pubic joint cartilage into a more flexible and elastic interpubic ligament in order to accommodate the enlarging uterus [11]. In non-pregnant rats, relaxin administration alone or in combination with estrogen reduces pubic symphysis collagen content, with progesterone antagonizing this effect [12]. Meanwhile, during pregnancy in rats, relaxin was reported to regulate collagen catabolism in the pubic symphysis [13]. In lower species such as rodents, relaxin action may be more reflective than in humans where serum relaxin level was found to have no link to the generalized joint laxity [14].

Relaxin affects tissues' extracellular matrix components including collagen, $\mathrm{H}_{2} \mathrm{O}$ and hyaluronan. Relaxin increases cervical hyaluronan content by up-regulating the expression of hyaluronic acid synthase [15]. This effect will result in loosening of tissues' dense collagen fiber network. Relaxin has been shown to possess anti-fibrotic action by down-regulating fibroblast activity, increasing collagenases synthesis and inhibit transforming growth factor (TGF- $\beta$ )-stimulated collagen-1 lattice contraction in rat kidney [16]. Relaxin up-regulates matrix metalloproteinases (MMP), a family of extracellular proteases that interfere with matrix remodeling by their ability to degrade extracellular matrix components including collagen [17]. Relaxin has been reported to stimulate the expression of collagenase-1, MMP-1, MMP-3 [18], MMP-9, and MMP-13 in fibrocartilaginous cells [19] and MMP-2 in periodontal ligament cells [20, 21].

Sex-steroids have been reported to affect relaxin receptor expression. In the human endometrium, relaxin receptor isoforms expression vary across the menstrual cycle with low level expressed during the proliferative phase and rises sharply at the time of ovulation [22]. In neonatal porcine uterus, estrogen increases RXFP1 mRNA expression, while in cervix, estrogen increases and relaxin decreases the expression of this receptor [23]. During late pregnancy in mice, relaxin has no influence on RXFP1 expression [24]. Progesterone has been reported to increase the expression of RXFP1 in the pregnant rat uteri [25] while estrogen was found to regulate RXFP1 mRNA expression in human cervix at term [26].

Knee is another potential target for relaxin action. Currently, little is known with regards to the expression of RXFP1 and RXFP2 in the knee. Wang et al. [27] reported that relaxin receptors were expressed in mouse knee fibrocartilage. In humans, relaxin receptors have been identified in the anterior cruciate ligament (ACL) in male and female knee [28], with higher expression in female [29]. This gender specific difference suggests the influence by female sex hormones. Apart from ACL, the expression of relaxin receptors in other knee structures including patellar tendon and lateral collateral ligament is currently unknown. Together with ACL, they participate in the control of knee stability during movement.

We hypothesized that female sex hormones affect RXFP1 and RXFP2 expression in the patellar tendon and lateral collateral ligament, thus affecting knee laxity. This could explain differences in the incidence of non- contact knee injury between male and female [30], and in female at different phases of the menstrual cycle [31]. In view of this, we investigated these isoforms expression in the patellar tendon and lateral collateral ligament in rat model in order to provide the mechanism underlying changes in knee laxity under different sex-steroid influence.

\section{Materials and Methods}

\section{Animal Preparation and Hormone Treatment}

All procedures involving experimental animals were approved by the Faculty of Medicine Animal Care and Use Committee (ACUC), University of Malaya (UM) with ethics number: FIS/22/11/2011/FD(R). Adult female WKY rats weighing 180-220 grams, obtained from the Animal House, Faculty of Medicine, UM were caged in a group of six, in a clean and well ventilated standard environment of 12 hours light: dark cycle. The animals had free access to soy-free diet (Gold Coin Pellet) and tap water ad libitum. Female WKY rats were ovariectomized ten days prior to steroid treatment to eliminate the effect of endogenous sex-steroids as previously described [32].

The animals were then divided into 8 groups ( $\mathrm{n}=6$ per group): Groups 1-4 received different doses of estrogen $(0.2,2,20$ and $50 \mu \mathrm{g} / \mathrm{kg})$ for three days with administration of $0.2 \mu \mathrm{g} / \mathrm{kg}$ estrogen was intended to achieve physiological plasma estrogen level in female rats [32]., Similarly, administration of higher estrogen doses were intended to produce hyperestrogenic conditions [33]. Group 5 received 3 days treatment with $4 \mathrm{mg} / \mathrm{kg}$ progesterone, which was administered to achieve the maximum physiological plasma level in female rats during oestrous cycle [32, 34]. Groups 6-7 received 3 days treatment with 125 and $250 \mu \mathrm{g} / \mathrm{kg}$ testosterone, [35], which will achieve a plasma level lower than the physiological level reported in the male rats (following $500 \mu \mathrm{g} / \mathrm{ml}$ testosterone administration) [36]. In humans, the premenoupasal plasma testosterone level was reported to be between 0.6 to $0.7 \mathrm{ng} / \mathrm{ml}$ [37]. In view of this, the doses used in this study i.e. $125 \mu \mathrm{g} / \mathrm{kg}$ and $250 \mu \mathrm{g} / \mathrm{kg}$ testosterone would contribute to physio- 
logical and supra-physiological plasma levels in female rats respectively (Refer Table 1 for plasma level for the related doses of hormones administered). Group 8 is a control group which received peanut oil (vehicle) for three days. All drugs were dissolved in peanut oil and were administered via subcutaneous injection behind the neck. To substantiate the amount of hormone reaches the blood circulation following subcutaneous injection,blood samples were withdrawn by heart puncture immediately following decapacitation and plasma concentrations of each hormone were determined by radioimmunoassay (RIA) in both treated and non-treated groups (control).

Table I: Plasma sex steroid level following subcutaneous hormone injection. Values were given as mean \pm standard error of mean. $E-$ estrogen, $\mathrm{P}$ - progesterone and $\mathrm{T}-$ testosterone. The level of hormones in the blood correlates with the amount injected via the subcutaneous route.

\begin{tabular}{ll}
\hline Treated samples & Hormone level (Mean \pm SD) \\
\hline Estrogen & \\
Control & $39.4 \pm 0.14 \mathrm{pg} / \mathrm{ml}$ \\
$0.2 \mu \mathrm{g} / \mathrm{kg} \mathrm{E}$ & $69.7 \pm 0.12 \mathrm{pg} / \mathrm{ml}$ \\
$2 \mu \mathrm{g} / \mathrm{kg} \mathrm{E}$ & $195.2 \pm 0.31 \mathrm{pg} / \mathrm{ml}$ \\
$20 \mu \mathrm{g} / \mathrm{kg} \mathrm{E}$ & $267.7 \pm 0.76 \mathrm{pg} / \mathrm{ml}$ \\
$50 \mu \mathrm{g} / \mathrm{kg} \mathrm{E}$ & $329.4 \pm 2.33 \mathrm{pg} / \mathrm{ml}$ \\
Progesterone & \\
Control & $4.18 \pm 0.11 \mathrm{ng} / \mathrm{ml}$ \\
$4 \mathrm{mg} / \mathrm{kg} \mathrm{P}$ & $23.67 \pm 0.13 \mathrm{ng} / \mathrm{ml}$ \\
Testosterone & \\
Control & $0.25 \pm 0.004 \mathrm{ng} / \mathrm{ml}$ \\
$125 \mu \mathrm{g} / \mathrm{kg} \mathrm{T}$ & $0.89 \pm 0.005 \mathrm{ng} / \mathrm{ml}$ \\
$250 \mu \mathrm{g} / \mathrm{kg} \mathrm{T}$ & $1.07 \pm 0.002 \mathrm{ng} / \mathrm{ml}$ \\
\hline
\end{tabular}

\section{mRNA Expression Analysis by Real Time PCR (qPCR)}

Patellar tendon, also known as patellar ligament which connects patellar to tibia tuberosity and lateral collateral ligament (LCL), which connects lateral epicondyle of the femur to the head of the fibula at the lateral side of the knee joint were harvested from rat's left hind leg. Both ligaments are extracapsular. Tissues were subsequently separated from their bony attachment and were immediately rinsed with $0.1 \%$ phosphate buffer. These tissues were kept in the RNALater solution (Ambion, USA) prior to RNA extraction. Total RNA was isolated from $30 \mathrm{mg}$ (wet weight) using Ribo pure kit (Ambion, USA). The RNA purity and concentration was assessed by $260 / 280 \mathrm{UV}$ absorption ratios (Gene Quant 1300, UK). One step real time PCR was used to evaluate gene expression, with the application of TaqMan® RNA-to-CT 1-Step Kit. Hprt1 and GAPDH were used as reference genes. TaqMan primer and probe for RXFP1, RXFP2, GAPDH and Hprt1 were obtained from predesigned assays from Applied Biosystems, USA. All experiments were done in 3 biological replicates. PCR program include 15 minutes at $48^{\circ} \mathrm{C}$ reverse transcriptase, 10 minutes at $95^{\circ} \mathrm{C}$ activation of ampli Taq gold DNA polymerase, denaturation at $95^{\circ} \mathrm{C}$ for 15 second and annealing at $60^{\circ} \mathrm{C}$ for 1 minute. Denature and annealing steps were performed for 40 cycles. Step one plus real time PCR machine, master mix and assays were purchased from Applied Biosystems, USA. The fold change of each target per average of GAPDH and Hprt1 was calculated and was considered as the mRNA expression level of the target gene. Data was analyzed according to Comparative Ct $(2-\Delta \Delta C t)$ method [38], where amplification of the target and of the reference genes were measured in the samples and reference. Measurements were normalized using GenEx software. Data Assist v3 software from Applied Biosystems, USA was used to calculate the RNA fold changes.

\section{Protein Expression Analysis by Western Blotting}

Patellar tendon and lateral collateral ligament were removed from their bony attachment of rat's left hind leg as earlier described. These tissues were then snapped frozen in liquid nitrogen and stored at $-80^{\circ} \mathrm{C}$ prior to protein extraction. The total amount of protein was extracted from $50 \mathrm{mg}$ tissue (wet weight). Following total protein extraction with PRO-PREP (Intron, UK), equal amount of protein from each tissue lysate were mixed with a loading dye, boiled for 5 minutes and separated by SDS-PAGE $12 \%$. The protein was then transferred onto a PVDF membrane (BIORAD, UK) and blocked with 5\% BSA for 90 minutes at room temperature. The membrane was exposed to rabbit polyclonal primary RXFP-1/LGR7 antibody (Abcam, UK), mouse polyclonal RXFP2/LGR8 (Abcam, UK) and rabbit anti-mouse beta actin (Abcam, UK) diluted at 1:1000 in PBS containing 1\% BSA and tween-20 for 90 minutes. Blots were washed three times with each lasted for five minutes, and were then incubated with anti-rabbit and anti-mouse horseradish peroxidase conjugated secondary antibodies (Santa Cruz) at a dilution of 1:2000, for 1 hour. The membrane was then washed and subjected to Opti-4CN ${ }^{\mathrm{TM}}$ Substrate Kit from Bio-Rad to visualize the protein bands. Photos of the blots were captured by a gel documentation system and the density of each band was determined using Image $\mathrm{J}$ software. Ratio of each target band $/ \beta$ actin was calculated and was considered as the expression level of the target proteins.

\section{Statistical Analysis}

One way Anova, with Tukey's post hoc test, was 
used to determine the level of significance with $\mathrm{p}<$ 0.05 was considered as significant. Meanwhile, Shapiro-Wilk test was further applied to evaluate data normality and homogeneity [39]. In this test, $p$ value greater than $\alpha$ level of 0.05 indicates that data came from a normally distributed population. For real time PCR and Western blotting, 6 rats were used per treatment groups. Density of each band in Western blotting was analyzed using Image J software, and the results were presented as the ratio of the target proteins to $\beta$-actin.

\section{Results}

\section{Plasma Sex-Steroid Levels following Subcutaneous Hormone Injection}

In table 1, the average hormones level in the blood in different groups of treatment is shown. Our findings indicate that serum levels of estrogen and testosterone correlate with the doses administered. Subcutaneous injection of $0.2 \mu \mathrm{g} / \mathrm{kg}$ estrogen resulted in plasma level of approximately two times higher than the control while injection of $4 \mathrm{mg}$ progesterone resulted in five times higher level than the control.

\section{RXFPI and RXFP2 Proteins Expression in the Patellar Tendon and Lateral Collateral Ligament}

In figure 1, the expression of RXFP1 protein is the highest in the lateral collateral ligament of progesterone treated rats with 1.75 fold increase as compared to control. Treatment with estrogen at 0.2 $\mu \mathrm{g} / \mathrm{kg}$ resulted in a slight but significant increase in the expression of RXFP1 protein as compared to control $(\mathrm{p}<0.05)$. Treatment with higher estrogen doses $(>2 \mu \mathrm{g} / \mathrm{kg})$ resulted in a dose-dependent increase in RXFP1 protein expression with 43 and 100 percent increase following treatment with 20 and $50 \mu \mathrm{g} / \mathrm{kg}$ estrogen respectively. Testosterone treatment resulted in a significant decrease in the expression of RXFP1 ( 0.54 and 0.45 fold increase following subcutaneous administration of 125 and $250 \mu \mathrm{g} / \mathrm{kg}$ testosterone respectively).

In figure 3, the expression of RXFP1 protein in the patellar tendon following treatment with $4 \mathrm{mg}$ progesterone is 2.71 folds higher than the control. Estrogen treatment resulted in a dose-dependent increase in this protein expression (1.25 to 2.67 fold increase following treatment with estrogen at doses between 0.2 to $50 \mu \mathrm{g} / \mathrm{kg}$ ). Testosterone treatment resulted in a dose-dependent decrease in RXFP1 protein expression ( 0.65 and 0.51 fold decrease) following treatment with 125 and $250 \mu \mathrm{g}$ testosterone respectively. The expression of RXFP1 protein in the patellar tendon was higher than the lateral collateral ligament.
In figure 5, the expression of RXFP2 protein in the lateral collateral ligament was the highest following treatment with progesterone $(0.93$ fold increase as compared to control) $(\mathrm{p}<0.05)$. A dose-dependent increase in the expression of RXFP2 protein was observed following treatment with increasing doses of estrogen (0.93 to 1.09 fold increase with estrogen doses between 0.2 to $50 \mu \mathrm{g} / \mathrm{kg}$ ). Treatment with $0.2 \mu \mathrm{g} / \mathrm{kg}$ estrogen did not result in a significant increase in RXFP2 protein expression as compared to control. Treatment with 125 and $250 \mu \mathrm{g} / \mathrm{kg}$ testosterone resulted in a significant decrease in the expression of RXFP2 protein, with 13 and 14 percent reduction as compared to control.

In figure 7 , the expression of RXFP2 protein in the patellar tendon was the highest following progesterone treatment ( 1.28 fold increase as compared to control). Treatment with increasing doses of estrogen resulted in a dose-dependent increase in RXFP2 protein expression; although the increase observed following $0.2 \mu \mathrm{g} / \mathrm{kg}$ estrogen treatment was not significantly differ from the control. A significant reduction in RXFP2 protein expression was noted following treatment with $250 \mu \mathrm{g}$ testosterone, which was 21.9 percent lower than the control. In the patellar tendon, the expression of RXFP1 exceeds RXFP2 by more than two times in particular following treatment with high estrogen doses (20 and $50 \mu \mathrm{g} / \mathrm{kg}$ ) and progesterone.

\section{RXFP I and RXFP2 mRNAs Expression in the Patellar Tendon and Lateral Collateral Ligament}

In figure 2, following progesterone treatment, the expression of RXFP1 mRNA in the lateral collateral ligament was 2.71 folds higher as compared to control. The lowest expression was noted following treatment with $250 \mu \mathrm{g}$ testosterone, which was 27 percent lesser than the control. Treatment with estrogen resulted in a dose-dependent increase in RXFP1 mRNA expression (1.21 to 2.13 fold increase following treatment with 0.2 to $50 \mu \mathrm{g} / \mathrm{kg}$ estrogen).

In figure 4, the expression of RXFP1 mRNA in the patellar tendon was the highest following treatment with progesterone ( 2.86 fold increase as compared to control). Treatment with testosterone at 125 and $250 \mu \mathrm{g} / \mathrm{kg}$ resulted in a significant reduction in RXFP1 mRNA expression as compared to control $(\mathrm{p}<0.05)$, with 16 and 26 percent decrease respectively. Estrogen administration resulted in a dose-dependent increase in the expression of RXFP1 mRNA (1.63 to 2.23 fold increase following treatment with 0.2 to $50 \mu \mathrm{g} / \mathrm{kg}$ estrogen), which were significantly higher than the control $(p<0.05)$. The level of expression of RXFP1 in the patellar tendon was higher than its expression in the lateral collateral ligament. 
In figure 6, the expression of RXFP2 mRNA in the lateral collateral ligament was increased following progesterone treatment which was 1.58 fold higher than the control. Estrogen treatment resulted in a dose-dependent increase in RXFP2 mRNA expression (1.13 to1.43 fold increase following treatment with 0.2 to $50 \mu \mathrm{g} / \mathrm{kg}$ estrogen). Treatment with low dose estrogen $(0.2 \mu \mathrm{g} / \mathrm{kg})$ however did not result in any significant change in the mRNA expression, while treatment with higher estrogen doses $(>2 \mu \mathrm{g} / \mathrm{kg})$ resulted in a significant increase in the mRNA level as compared to control. Testosterone treatment at 125 and $250 \mu \mathrm{g} / \mathrm{kg}$ resulted in a significant decrease in RXFP2 mRNA expression as compared to $0.2 \mu \mathrm{g} / \mathrm{kg}$ estrogen and the control $(\mathrm{p}<0.05)$.

In figure 8 , the expression of RXFP2 mRNA in the patellar tendon was the highest following treatment with progesterone (2.28 fold increase as compared to control). Estrogen treatment resulted in a dose-dependent increase in RXFP2 expression (1.13 to 2.01 fold increase following treatment with 0.2 to $50 \mu \mathrm{g} / \mathrm{kg}$ estrogen). Treatment with 125 and $250 \mu \mathrm{g} / \mathrm{kg}$ testosterone resulted in a significant reduction in RXFP2 mRNA expression ( 0.79 and 0.5 fold- respectively) as compared to control. RXFP2 mRNA expression in the patellar tendon exceeds its expression in the lateral collateral ligament only following treatment with $50 \mu \mathrm{g} / \mathrm{kg}$ estrogen and progesterone.

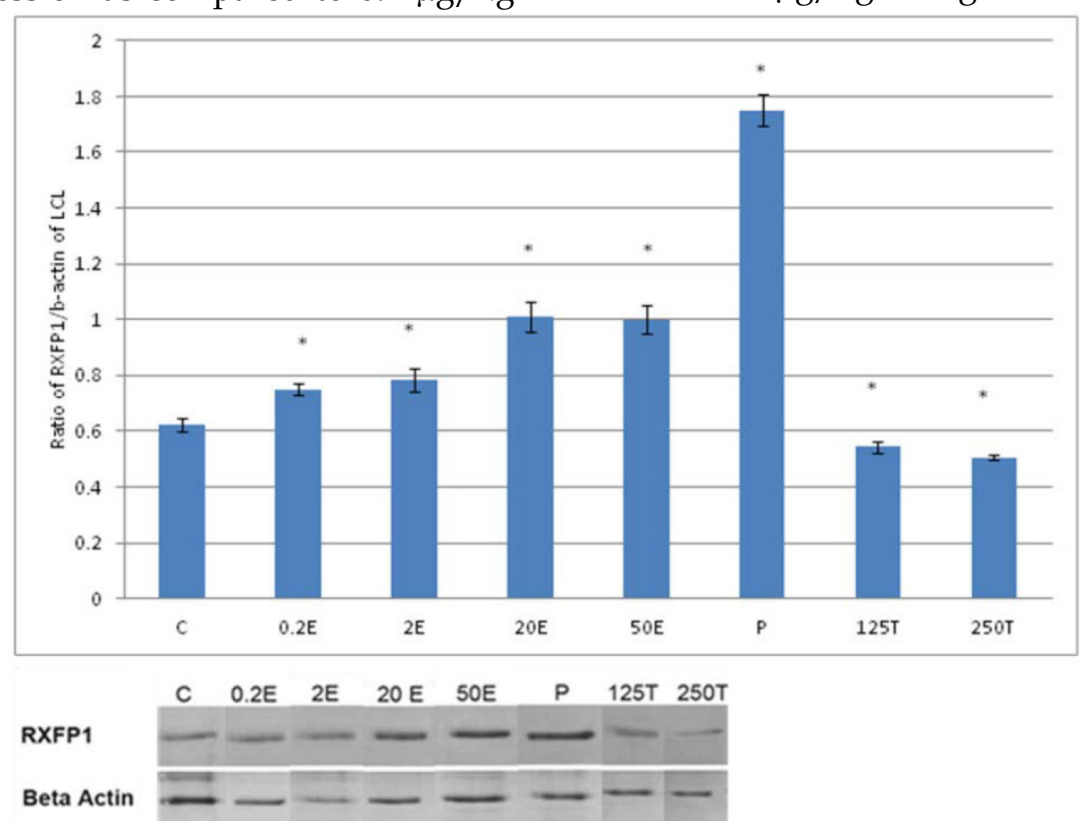

Figure I: The expression of RXFPI protein in the total homogenate of lateral collateral ligament from ovariectomised rats treated with different sex-steroids: C- control; $0.2 \mathrm{E}$ $-0.2 \mu \mathrm{g} / \mathrm{kg}$ estrogen; $2 \mathrm{E}-2 \mu \mathrm{g} / \mathrm{kg}$ estrogen, $20 \mathrm{E}-20 \mu \mathrm{g} / \mathrm{kg}$ estrogen; $50 \mathrm{E}-50 \mu \mathrm{g} / \mathrm{kg}$ estrogen; $\mathrm{P}-4 \mathrm{mg}$ progesterone; $125 \mathrm{~T}-125 \mu \mathrm{g}$ testosterone; $250 \mathrm{~T}-250 \mu \mathrm{g}$ testosterone, $\mathrm{LCL}$-lateral collateral ligament. Data were expressed as mean $\pm \mathrm{SEM}, \mathrm{n}=6$ per treatment group. ${ }^{*} \mathrm{p}<0.05$ as compared to control, Shapiro-Wilk test, $\mathrm{P}=0.3 \mathrm{I} 9732$. $\mathrm{A}$ dose-dependent increase in RXFPI protein expression was observed following estrogen treatment. Progesterone caused the highest increase while testosterone caused a decrease in this isoform expression. The image was cut in order to arrange the bands in sequence with the label on the $x$-axis of the bar chart.

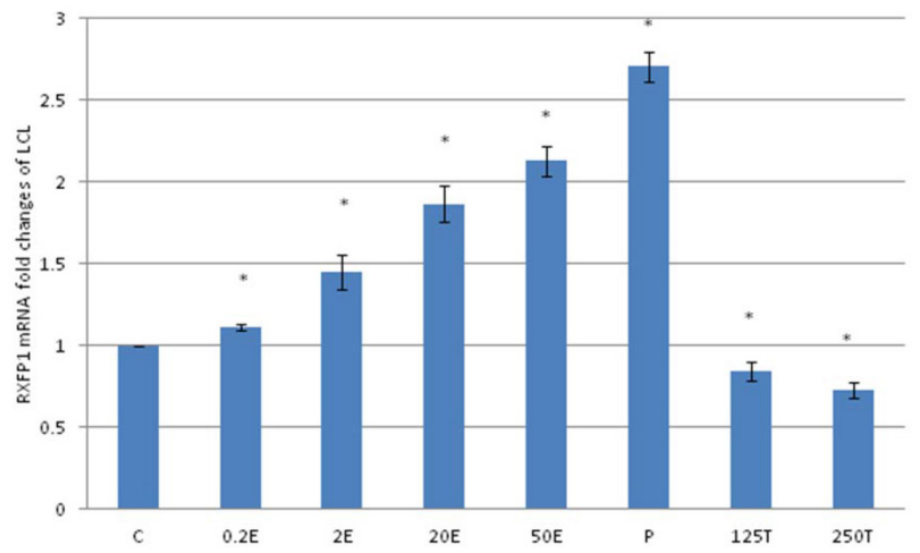

Figure 2: The expression of RXFPI mRNA in lateral collateral ligament from ovariectomised rats treated with different sex-steroids: C- control; $0.2 \mathrm{E}-0.2 \mu \mathrm{g} / \mathrm{kg}$ estrogen; $2 \mathrm{E}$

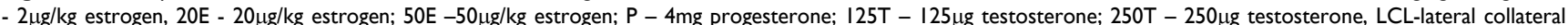
ligament. Data were expressed as mean \pm SEM, $n=6$ per treatment group. ${ }^{*} p<0.05$ as compared to control, Shapiro-Wilk test, $p=0.3$ I 33 I 9 . A dose-dependent increase in $R X F P I$ mRNA expression was noted with increasing doses of estrogen. Progesterone treatment caused the highest increase while testosterone caused a dose-dependent decrease in RXFPI mRNA expression 


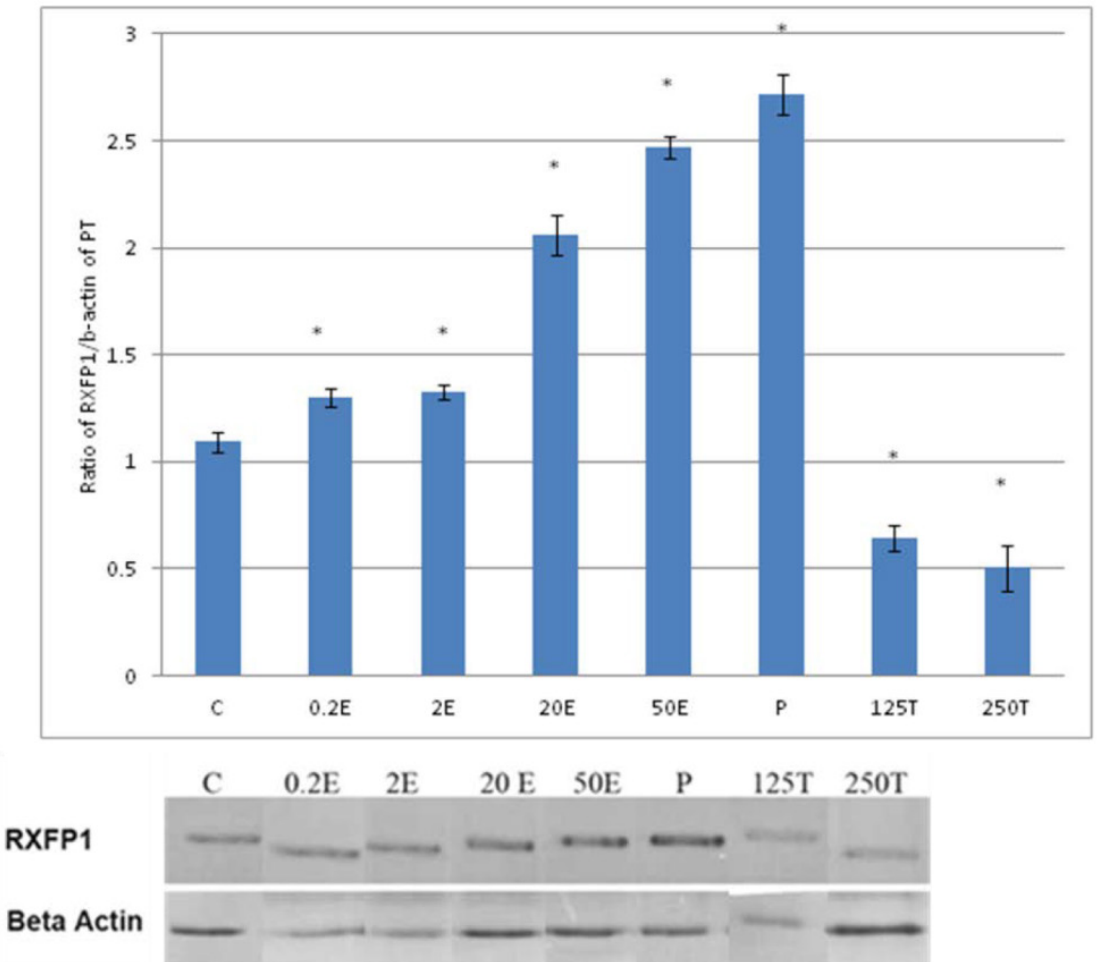

Figure 3: The expression of RXFPI protein in the total homogenate of the patellar tendon from ovariectomised rats treated with different sex-steroids: C- control; $0.2 \mathrm{E}-$ $0.2 \mu \mathrm{g} / \mathrm{kg}$ estrogen; $2 \mathrm{E}-2 \mu \mathrm{g} / \mathrm{kg}$ estrogen, $20 \mathrm{E}-20 \mu \mathrm{g} / \mathrm{kg}$ estrogen; $50 \mathrm{E}-50 \mu \mathrm{g} / \mathrm{kg}$ estrogen; $\mathrm{P}-4 \mathrm{mg}$ progesterone; $125 \mathrm{~T}$ - $125 \mu \mathrm{g}$ testosterone; $250 \mathrm{~T}-250 \mu \mathrm{g}$ testosterone PTpatellar tendon. Data were expressed as mean \pm SEM, $n=6$ per treatment group. $* p<0.05$ as compared to control, Shapiro-Wilk test, $p=0.282109$. A marked increase in the expression of RXFPI protein occurs following treatment with high doses of estrogen $(20 \& 50 \mu \mathrm{g} / \mathrm{kg})$. Meanwhile, progesterone treatment caused the highest increase while testosterone caused a decrease in RXFPI protein expression in the tendon. The image was cut in order to arrange the bands in sequence with the label on the $x$-axis of the bar chart.

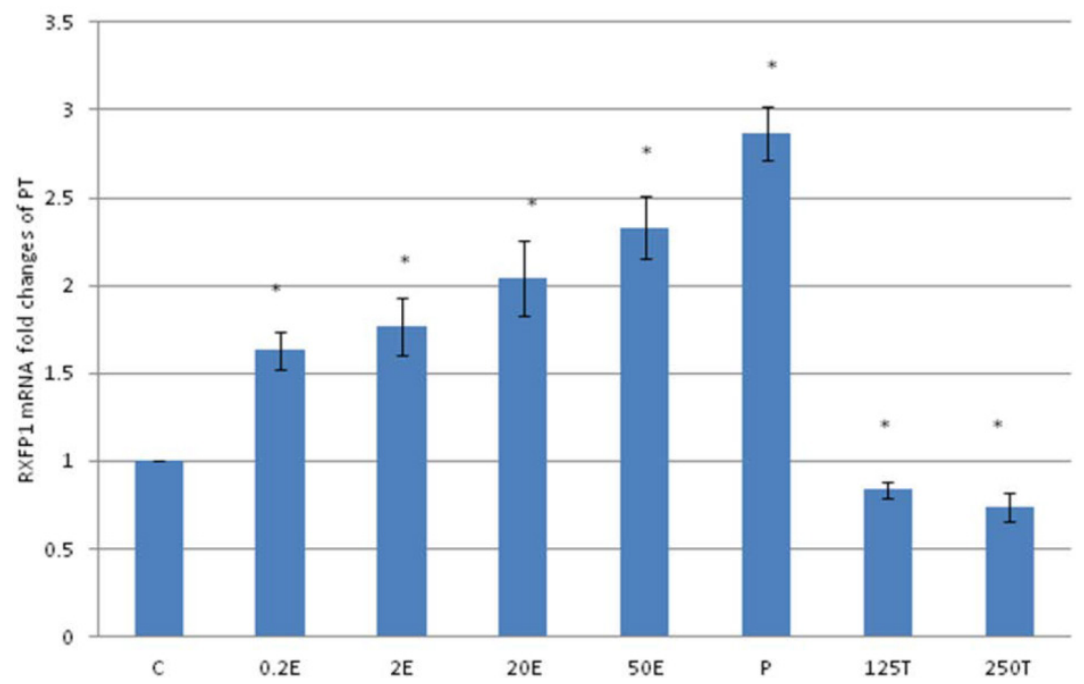

Figure 4: The expression of RXFPI mRNA in the patellar tendon from ovariectomised rats treated with different sex-steroids: C- control; $0.2 \mathrm{E}-0.2 \mu \mathrm{g} / \mathrm{kg}$ estrogen; $2 \mathrm{E}-2 \mu \mathrm{g} / \mathrm{kg}$

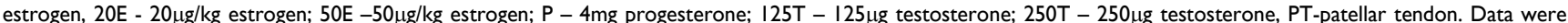
expressed as mean \pm SEM, $n=6$ per treatment group. $* p<0.05$ as compared to control, Shapiro-Wilk test, $p=0.207574$. A dose-dependent increase in RXFPI mRNA was noted following increasing dose of estrogen. Meanwhile progesterone treatment resulted in the highest increase while testosterone reduced the mRNA expression. 


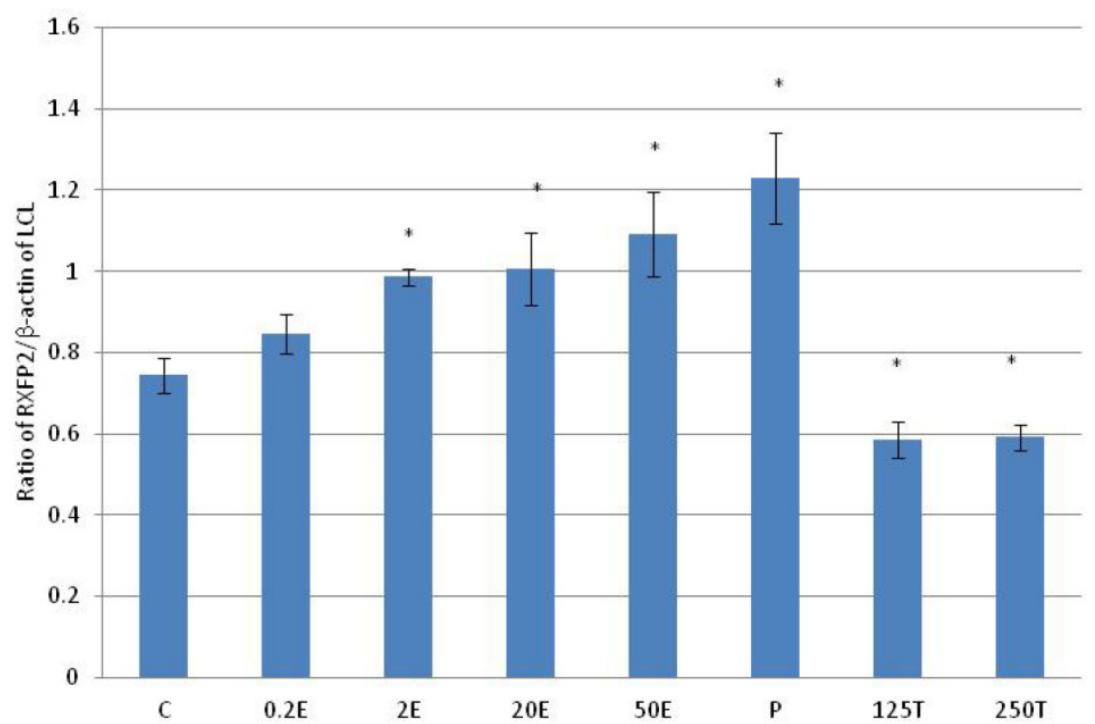

RXFP2

Beta Actin
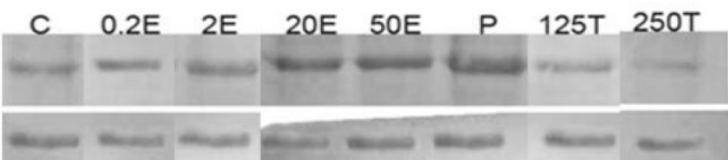

Figure 5: The expression of RXFP2 protein in the total homogenate of the lateral collateral ligament from ovariectomised rats treated with different sex-steroids: C- control; $0.2 \mathrm{E}-0.2 \mu \mathrm{g} / \mathrm{kg}$ estrogen; $2 \mathrm{E}-2 \mu \mathrm{g} / \mathrm{kg}$ estrogen, $20 \mathrm{E}-20 \mu \mathrm{g} / \mathrm{kg}$ estrogen; $50 \mathrm{E}-50 \mu \mathrm{g} / \mathrm{kg}$ estrogen; $\mathrm{P}-4 \mathrm{mg}$ progesterone; $125 \mathrm{~T}-125 \mu \mathrm{g}$ testosterone; $250 \mathrm{~T}-250 \mu \mathrm{g}$ testosterone, LCL-lateral collateral ligament. Data were expressed as mean \pm SEM, $n=6$ per treatment group. ${ }^{*} p<0.05$ as compared to control, Shapiro-Wilk test, $p=0.776415$. The expression of RXFP2 protein was increased following treatment with estrogen at doses exceeding $2 \mu \mathrm{g} / \mathrm{kg}$. Meanwhile, progesterone caused the highest increase while testosterone caused a decrease in RXFP2 protein expression. The image was cut in order to arrange the bands in sequence with the label on the $x$-axis of the bar chart.

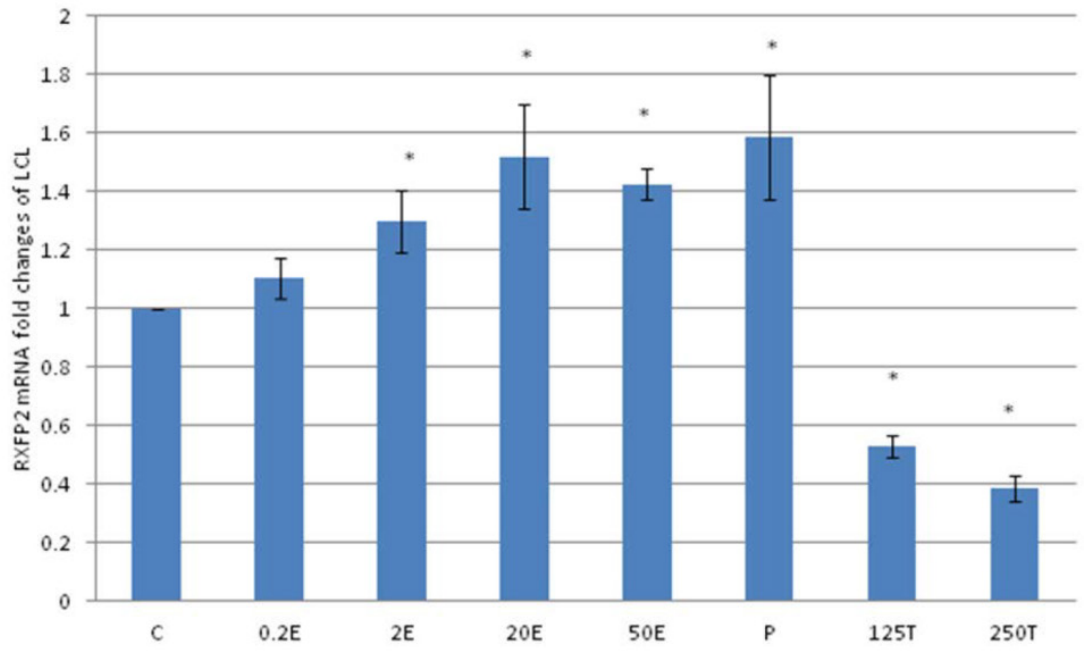

Figure 6: The expression of RXFP2 mRNA in the lateral collateral ligament from ovariectomised rats treated with different sex-steroids: C- control; $0.2 \mathrm{E}-0.2 \mu \mathrm{g} / \mathrm{kg}$ estrogen; $2 \mathrm{E}-2 \mu \mathrm{g} / \mathrm{kg}$ estrogen, $20 \mathrm{E}-20 \mu \mathrm{g} / \mathrm{kg}$ estrogen; $50 \mathrm{E}-50 \mu \mathrm{g} / \mathrm{kg}$ estrogen; P - 4mg progesterone; $125 \mathrm{~T}$ - I25 $\mu \mathrm{g}$ testosterone; $250 \mathrm{~T}-250 \mu \mathrm{g}$ testosterone, LCL-lateral collateral ligament. Data were expressed as mean \pm SEM, $n=6$ per treatment group. * $p<0.05$ as compared to control, Shapiro-Wilk test, $p=0.668854$. Treatment with estrogen at doses exceeding $2 \mu \mathrm{g} / \mathrm{kg}$ resulted in a dose-dependent increase in RXFP2 mRNA expression. Meanwhile, progesterone caused the highest increase while testosterone treatment resulted in a decrease in this isoform mRNA expression. 

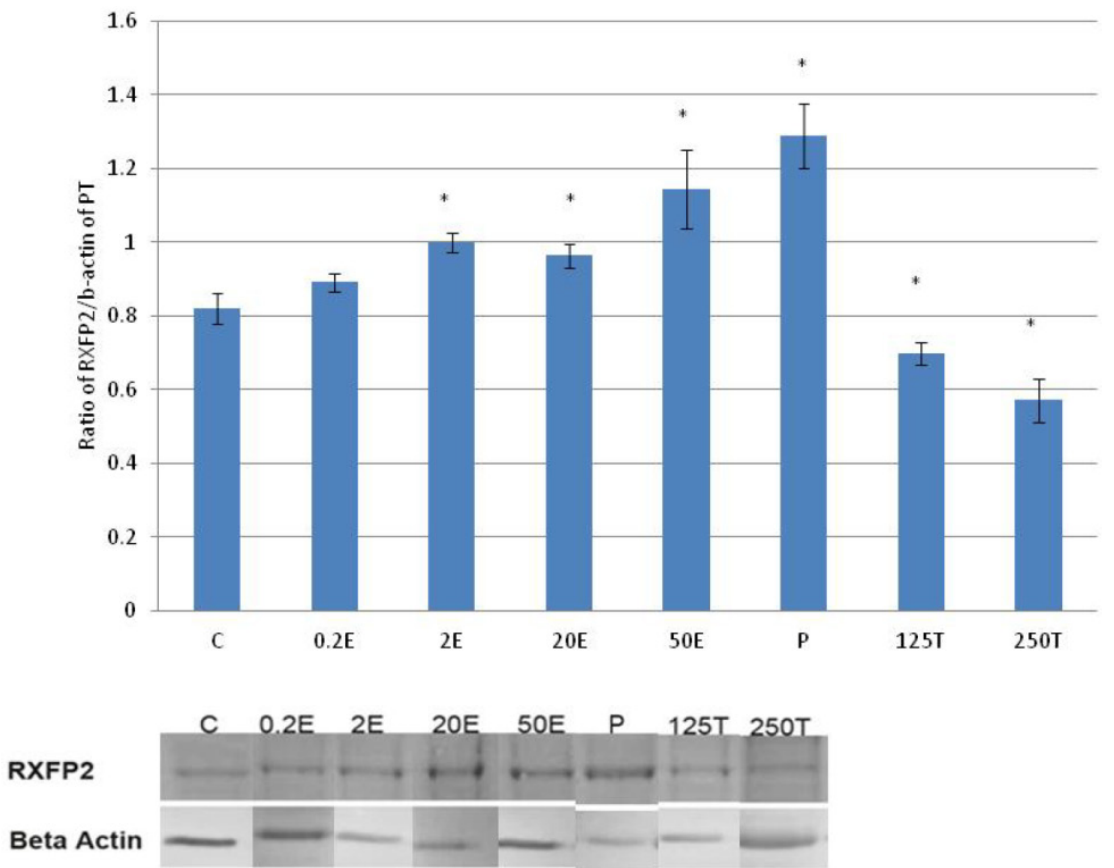

Figure 7: The expression of RXFP2 protein in the total homogenate of the patellar tendon from ovariectomised rats treated with different sex-steroids: C- control; $0.2 \mathrm{E}-$ $0.2 \mu \mathrm{g} / \mathrm{kg}$ estrogen; $2 \mathrm{E}-2 \mu \mathrm{g} / \mathrm{kg}$ estrogen, $20 \mathrm{E}-20 \mu \mathrm{g} / \mathrm{kg}$ estrogen; $50 \mathrm{E}-50 \mu \mathrm{g} / \mathrm{kg}$ estrogen; $\mathrm{P}-4 \mathrm{mg}$ progesterone; $125 \mathrm{~T}-125 \mu \mathrm{g}$ testosterone; $250 \mathrm{~T}-250 \mu \mathrm{g}$ testosterone, PT-patellar tendon. Data were expressed as mean \pm SEM, $n=6$ per treatment group. ${ }^{*} p<0.05$ as compared to control, Shapiro-Wilk test, $p=0.736386$. An increase in the expression of RXFP2 protein was noted following treatment with estrogen exceeding $2 \mu \mathrm{g} / \mathrm{kg}$. Progesterone treatment resulted in the highest increase while testosterone caused a dose-dependent decrease in the expression of this protein isoform. The image was cut in order to arrange the bands in sequence with the label on the $\mathrm{x}$-axis of the bar chart.

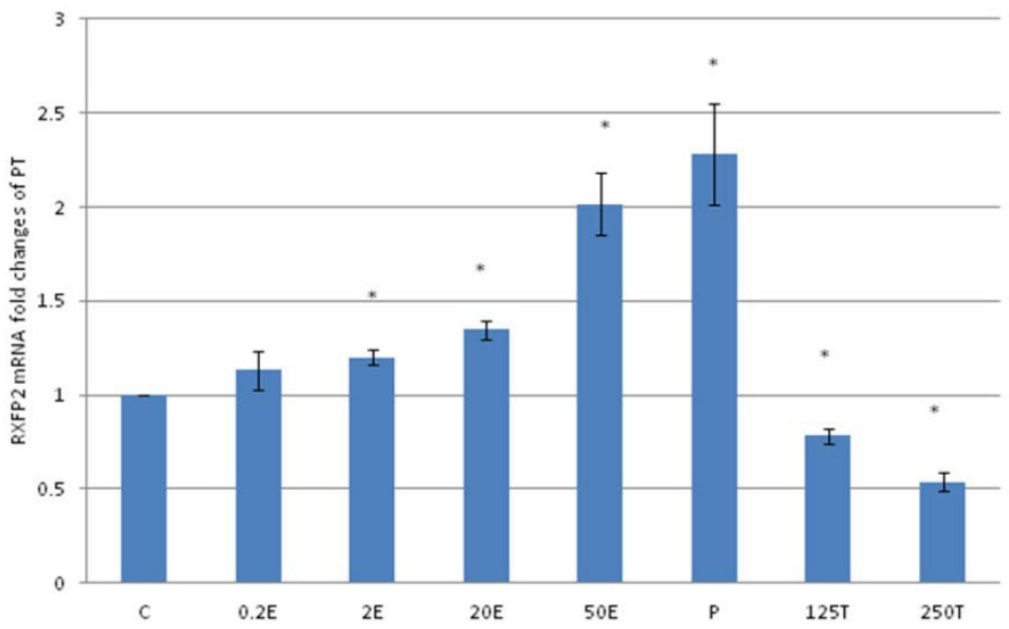

Figure 8: The expression of RXFP2 mRNA in the patellar tendon from ovariectomised rats treated with different sex-steroids: C- control; $0.2 \mathrm{E}-0.2 \mu \mathrm{g} / \mathrm{kg}$ estrogen; $2 \mathrm{E}$ - $2 \mu \mathrm{g} / \mathrm{kg}$

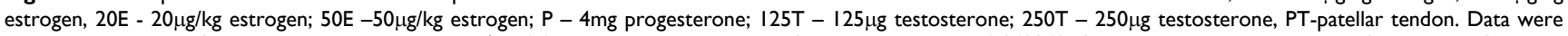
expressed as mean \pm SEM, $n=6$ per treatment group. ${ }^{*} p<0.05$ as compared to control, Shapiro-Wilk test, $p=0.842243$. An increase in the RXFPI mRNA was noted following treatment with estrogen at doses exceeding $2 \mu \mathrm{g} / \mathrm{kg}$. Progesterone treatment resulted in the highest increase while testosterone caused a dose-dependent decrease in RXFP2 mRNA expression.

\section{Discussion}

Our findings have revealed the followings: (i) The expression of RXFP1 protein and mRNA in knee lateral collateral ligament and patellar tendon were up-regulated by estrogen and progesterone, and were down-regulated by testosterone (ii) RXFP2 protein and mRNA expression were up-regulated by estrogen at doses exceeding $2 \mu \mathrm{g} / \mathrm{kg}$ and progesterone. Treatment with $0.2 \mu \mathrm{g} / \mathrm{kg}$ estrogen however had no signif- icant effect on the expression of this receptor isoform, (iii) The expression of RXFP1 protein and mRNA in the patellar tendon under the influence of estrogen and progesterone was higher than its expression in the lateral collateral ligament, (iv) No significant changes in RXFP2 expression was noted between patellar tendon and lateral collateral ligament except following treatment with $50 \mu \mathrm{g} / \mathrm{kg}$ estrogen and progesterone, where higher expression was noted in the former than the latter and (iv) RXFP1 is the main iso- 
form expressed in the patellar tendon and lateral collateral ligament of the rat knee joint.

The effect of relaxin on ligament laxity has long been reported [40]. The first evidence was documented by Hisaw in 1926 where relaxin infusion in mice was found to cause relaxation of the pelvic ligament [41]. Research related to relaxin effect on knee joint laxity has become increasingly important in the recent years due to the reported increase in the incidence of non-contact knee injury among the female athletes. Recent evidence suggested that plasma relaxin level correlates with the increase in incidence of ACL tear in elite female athletes [42]. In addition to knee, the laxity of trapezial-metacarpal joint in humans [14] and pubic ligaments in mice [11] has also been reported to change with changes in plasma relaxin level.

The influence of female sex-hormones on relaxin action in the knee ligaments has been proposed. In-vitro binding assay has revealed that relaxin binding to the female ACL was higher than male ACL. This finding was supported by the increase in the number of relaxin receptors expressed in the female ACL as compared to male [29]. Quantitation of relaxin receptors by radioligand binding assay in the human ACL fibroblast cells has revealed that relaxin binding was present in four out of five female ACL fibroblast as compared to one out of five male ACL fibroblast [28]. The direct influence of estrogen on ACL laxity has been documented by Dragoo et al [43] where three weeks combined infusion of estrogen and relaxin to the guinea pigs has resulted in increased anterior tibial dislocation, indicating an increase in ACL laxity. Meanwhile, in rabbit temporomandibular joint and pubic symphysis, concomitant administration of relaxin with estrogen was found to cause loss of glycosaminoglycans and collagen from these tissues, which will lead to an increase in the ligament laxity. Progesterone administration meanwhile prevented this effect [18].

Although this study has not provided direct evidence of an increase in the expression of relaxin receptors in the ACL under sex-steroid effect, we have for the first time shown that estrogen and progesterone upregulate the expression of relaxin receptor isoforms (RXFP1 and RXFP2) in the patellar tendon and lateral collateral ligament. In other tissues including uterus [25] and cervix [26], estrogen was also reported to upregulate the expression of the relaxin receptors. In this study, modulation of RXFP1 and RXFP2 expression by sex-steroids could provide the basis underlying the effect of these hormones on knee joint laxity. Recently, relaxin was also found to have significant effect on the patellar tendon stiffness in healthy, young and normally menstruating women
[44]. Although the actual mechanism is unknown, this effect could possibly be mediated through upregulation of RXFP1 and RXFP2 by sex-steroids, which levels fluctuate throughout the menstrual cycle. The mechanisms that lead to the changes in knee ligament laxity following the binding of relaxin to its receptors have been earlier discussed (introduction section).

Our findings have important implication as it could help to explain differences in the incidence of non-contact knee injury between male and female. Female was reported to have two to ten times higher risk of injury than male and is related to phases of the menstrual cycle [31] which pointed towards the involvement of sex-steroids. The effect of estrogen on RXFP1 and RXFP2 expression in the patellar tendon and lateral collateral ligament of rats' knee confirmed the involvement of this hormone in modulating knee laxity. At low dose $(0.2 \mu \mathrm{g} / \mathrm{kg})$, which correlate with the plasma estrogen level of $69.7 \pm 0.12 \mathrm{pg} / \mathrm{ml}$ (table $1)$, the expression of RXFP1 was higher than the control although no significant changes in RXFP2 expression were noted. The mean reported plasma estrogen level in the early follicular phase of the menstrual cycle was $31 \mathrm{pg} / \mathrm{ml}\left(0.31 \times 10^{-4} \mu \mathrm{g} / \mathrm{ml}\right)$ [45]. In rat at proestrous, estrogen level was found to be higher at $40.5 \mathrm{pg} / \mathrm{ml}\left(0.45 \times 10^{-4} \mu \mathrm{g} / \mathrm{ml}\right)$ [46]. In view that $0.2 \mu \mathrm{g} / \mathrm{kg}$ estrogen administration resulted in the plasma estrogen level of $69.7 \mathrm{pg} / \mathrm{ml}$, which was slightly higher than the level observed in humans and rats at the follicular phase and proestrus stage respectively, there is a possibility that this level could affect knee ligament laxity via upregulating the expression of relaxin receptor isoforms rendering the tissue to be more sensitive towards relaxin action.

Meanwhile, administration of 2, 20 and $50 \mu \mathrm{g} / \mathrm{kg}$ estrogen resulted in the circulating plasma level of $195.2 \pm 0.31,267.7 \pm 0.76$ and $329.4 \pm 2.33 \mathrm{pg} / \mathrm{ml}$ respectively (table 1). Treatment with estrogen at doses exceeding $2 \mu \mathrm{g} / \mathrm{kg}$ resulted in higher expression of RXFP1 and RXFP2 as compared to the control and $0.2 \mu \mathrm{g} / \mathrm{kg}$ estrogen. High estrogen level in the blood could be achieved at the time of ovulation, with the reported level of $400 \mathrm{pg} / \mathrm{ml}\left(0.4 \times 10^{-3} \mu \mathrm{g} / \mathrm{ml}\right)$ [45]. Shultz et al [47] reported that high incidence of non-contact knee injury occur in the pre-ovulatory phase, which suggested that increased estrogen level may have significant impact on the knee ligament laxity. Several other findings have also reported that increased incidence of non-contact knee injury during the ovulatory phases of the cycle [48-50] was related to the effect of high estrogen doses on knee ligament laxity. Estrogen- induced upregulation of relaxin receptors will augment relaxin effect on the knee.

High plasma estrogen can be achieved following 
consumption of oral contraceptive pills (OCP) that contains 15 to $50 \mu \mathrm{g}$ estrogen [51]. In the female athletes, OCP is consumed for birth control purpose and to prevent menstruation in order to improve their physical performance [52]. Few studies have reported that OCP intake could influence knee laxity; however their findings seem to be conflicting. Hicks-Little et al, [53] and Cammarata et al [54] reported that female on OCP tend to have higher knee laxity, while others reported the opposite [55]. Meanwhile, few other studies found no relationship between OCP consumption and knee ligament laxity [51, 56]. Differences in sex-steroid content between different $\mathrm{OCP}$ formulations could be the reason for this variability.

While estrogen has been shown to affect ACL laxity in the animal model [43], little is known with regards to the effect of progesterone and testosterone on knee ligament laxity. Dragoo et al, [57] measured serum relaxin concentration (SRC) in elite collegiate female athletes and had observed a positive correlation between SRC and serum progesterone concentration in athletes who are oligomenorrheic, eumenorrheic, not on oral contraceptive and have ovulatory cycle., In this study, serum progesterone level was measured to confirmed luteal phase measurement of relaxin as relaxin levels are known to be higher in this phase. Other studies involving female athletes have also indicated that knee laxity was increased during ovulation and in the luteal phase of the menstrual cycle [53]. Meanwhile, a positive correlation between changes in knee laxity and knee joint load has been reported from follicular phase to ovulation, and from ovulation to the luteal phase [49], where the latter phase is associated with high serum progesterone level. Our findings which revealed an up-regulation of RXFP1 and RXFP2 isoforms in the patellar tendon and lateral collateral ligament by progesterone further support these observations. The increase in these isoforms expression in the collateral ligaments predisposes the knee towards non-contact injury especially during excessive varus or valgus movement.

Progesterone upregulation of RXFP1 and RXFP2 expression in the knee was supported by findings in other tissues including the pregnant rat uteri, where this hormone was found to cause an increase in RXFP1 expression in the myometrium [25]. In the mammary glands, progesterone was reported to stimulate relaxin receptor expression which resulted in reduced breast laxity. This effect is due to a decrease in the collagen content of the mammary gland's extracellular matrix in the presence of relaxin [58]. In this study, the plasma level achieved following subcutaneous progesterone injection was $23.67 \pm 0.13$ $\mathrm{ng} / \mathrm{ml}$, which was slightly higher than the maximum plasma level reported during the luteal phase of the cycle in premenopausal female, at $17.02 \mathrm{ng} / \mathrm{ml}$ [59]. This indicate that the level of progesterone in the luteal phase can cause an increase in knee laxity, rendering the knee to be more susceptible towards a non-contact injury.

Finally, we have also observed that RXFP1 and RXFP2 expression in both patellar tendon and lateral collateral ligament was down-regulated by testosterone and this effect was dose-dependent. In the female, the presence of androgen receptor was reported in the ACL [60], suggesting that testosterone could influence knee laxity. Testosterone level was found to fluctuate throughout the menstrual cycle, with the highest level noted in the luteal phase [61].Down-regulation of RXFP1 and RXFP2 expression by testosterone in the patellar tendon and lateral collateral ligament indicated that knee laxity could be reduced under the influence of this hormone. A recent finding by $\mathrm{O}^{\prime}$ Leary et al, [62] indicated that prolonged aerobic exercise in women with normal menstrual cycle can induce a short-term elevation in plasma testosterone level. We hypothesized that a continuous short-burst in plasma testosterone may result in down-regulation of relaxin receptors in these knee structures, thus could help to reduce knee laxity in exercising women. In addition to this, testosterone has also been reported to increase the strength of the muscles that control knee joint movement [63]. Taken together, these findings may explain increased knee joint stiffness in female following testosterone administration.

In conclusion, our study has provided novel evidences that sex-steroid affect RXFP1 and RXFP2 expression in the patellar tendon and lateral colateral ligament of the rat knee joint.These findings are important as it may help to provide the basis underlying increased in incidence of non-contact knee injury in female as compared to male and in female at different phases of the menstrual cycle. Precaution however should be taken when projecting these findings to humans as recent evidence suggested that there was apparently no relationship between serum relaxin and joint laxity [14].

\section{Acknowledgment}

This study is supported by PPP grant, (PV104/2012A), University of Malaya, Kuala Lumpur, Malaysia.

\section{Conflict of interest}

There is no conflict of interest in this study. 


\section{References}

1. Park JI, Chang C, Hsu S. New Insights into Biological Roles of Relaxin and Relaxin-related Peptides. Rev Endocr Metab Disord 2005; 6(4):291-296.

2. Conrad KP, Baker VL. Corpus luteal contribution to maternal pregnancy physiology and outcomes in assisted reproductive technologies. American Journal of Physiology - Regulatory, Integrative and Comparative Physiology 2013; 304(2):R69-R72.

3. Scott DJ, Rosengren KJ, Bathgate RA. The Different Ligand-Binding Modes of Relaxin Family Peptide Receptors RXFP1 and RXFP2. Molecular Endocrinology 2012; 26(11):1896-1906.

4. Nair VB Samuel, C S, Separovic F, Hossain M A, Wade JD. Human relaxin-2: historical perspectives and role in cancer biology. Amino acids 2012;43(3):1131-1140

5. Scott DJ, Layfield S, Riesewijk A, Morita H, Tregear GW, Bathgate RA. Characterization of the mouse and rat relaxin receptors. Ann N Y Acad Sci 2005; 1041:8-12.

6. Rosengren KJ, Lin F, Bathgate RA, Tregear GW, Daly NL, Wade JD, Craik DJ. Solution structure and novel insights into the determinants of the receptor specificity of human relaxin-3. J Biol Chem 2006; 281(9):5845-5851.

7. Schwabe C, Büllesbach E. Relaxin, the Relaxin-Like Factor and Their Receptors. In: Relaxin and Related Peptides. Volume 612, edn. Edited by Agoulnik A: Springer New York; 2007;: 14-25.

8. Hayes E. Biology of primate relaxin: A paracrine signal in early pregnancy? Reproductive Biology and Endocrinology 2004;2(1):36.

9. Cernaro V, Lacquaniti A, Lupica R, Buemi A, Trimboli D, Giorgianni G, Bolignano D, Buemi M. Relaxin: New Pathophysiological Aspects and Pharmacological Perspectives for an Old Protein. Medicinal Research Reviews 2014; 34(1):77-105.

10. Sherwood OD, Downing SJ, Guico-Lamm ML, Hwang JJ, O'Day-Bowman MB, Fields PA. The physiological effects of relaxin during pregnancy: studies in rats and pigs. Oxf Rev Reprod Biol. 1993; 15:143-189.

11. Lippert TH, Steinburg A, Seeger H, Voelter W, Ruoff HJ. Dose response relationship of relaxin on the pubic ligament of the mouse. Clin Exp Obstet Gynecol 1987; 14(2):80-83.

12. Samuel CS, Butkus A, Coghlan JP, Bateman JF. The effect of relaxin on collagen metabolism in the nonpregnant rat pubic symphysis: the influence of estrogen and progesterone in regulating relaxin activity. Endocrinology 1996; 137(9):3884-3890.

13. Samuel CS, Coghlan J, Bateman JF. Effects of relaxin, pregnancy and parturition on collagen metabolism in the rat pubic symphysis. J Endocrinol 1998; 159:117-125.

14. Wolf JM, Williams AE, Delaronde S, Leger R, Clifton KB, King KB. Relationship of Serum Relaxin to Generalized and Trapezial-Metacarpal Joint Laxity. The Journal of hand surgery 2013; 38(4):721-728.

15. Soh YM, Tiwari A, Mahendroo M, Conrad KP, Parry LJ. Relaxin regulates hyaluronan synthesis and aquaporins in the cervix of late pregnant mice. Endocrinology 2012; 153(12):6054-6064.

16. Masterson R, Hewitson TD, Kelynack K, Martic M, Parry L, Bathgate RA, Darby I, Becker G. Relaxin down-regulates renal fibroblast function and promotes matrix remodelling in vitro. Nephrology Dialysis Transplantation 2004;19(3):544-552

17. Chow BS, Chew EG, Zhao C, Bathgate RA, Hewitson TD, Samuel CS. Relaxin signals through a RXFP1-pERK-nNOS-NO-cGMP-dependent pathway to up-regulate matrix metalloproteinases: the additional involvement of iNOS. PLoS One 2012;7(8):e42714.

18. Hashem G, Zhang Q, Hayami T, Chen J, Wang W, Kapila S. Relaxin and beta-estradiol modulate targeted matrix degradation in specific synovial joint fibrocartilages: progesterone prevents matrix loss. Arthritis Res Ther 2006; 8(4):R98.

19. Ahmad $\mathrm{N}$, Wang $\mathrm{W}$, Nair $\mathrm{R}$, Kapila $\mathrm{S}$. Relaxin induces matrix-metalloproteinases-9 and -13 via RXFP1: induction of MMP-9 involves the PI3K, ERK, Akt and PKC-zeta pathways. Molecular and Cellular Endocrinology 2012; 363(1-2):46-61.

20. Ho TY, Dilts MA,Bartol FF,Bagnell CA. Relaxin promotes matrix metalloproteinase-2 and decreases Wnt/beta-catenin expression in the neonatal porcine heart. Annals of the New York Academy of Sciences 2009; 1160:287-288.

21. Miao D, Fenno JC,Timm JC,Joo NE,Kapila YL. The Treponema denticola chymotrypsin-like protease dentilisin induces matrix metalloproteinase-2-dependent fibronectin fragmentation in periodontal ligament cells. Infection and immunity 2011; 79(2):806-811.

22. Bond CP, Parry LJ, Samuel CS, Gehring HM, Lederman FL, Rogers PAW, Summers RJ. Increased Expression of the Relaxin Receptor (LGR7) in Human Endometrium during the Secretory Phase of the Menstrual Cycle. Journal of Clinical Endocrinology \& Metabolism 2004; 89(7):3477-3485.

23. Yan W, Chen J, Wiley AA, Crean-Harris BD, Bartol FF, Bagnell CA. Relaxin (RLX) and estrogen affect estrogen receptor alpha, vascular endothelial growth factor, and RLX receptor expression in the neonatal porcine uterus and cervix. Reproduction 2008; 135(5):705-712.

24. Siebel AL, Gehring HM, Reytomas IG, Parry LJ. Inhibition of oxytocin receptor and estrogen receptor-alpha expression, but not relaxin receptors (LGR7), in the myometrium of late pregnant relaxin gene knockout mice. Endocrinology 2003; 144(10):4272-4275.

25. Vodstrcil LA, Shynlova O, Westcott K, Laker R, Simpson E, Wlodek ME, Parry LJ. Progesterone withdrawal, and not increased circulating relaxin, mediates the decrease in myometrial relaxin receptor (RXFP1) expression in late gestation in rats. Biol Reprod 2010; 83(5):825-832.

26. Maseelall P, Gardner J, Wojtczuk A, Weiss G, Goldsmith LT. Relaxin receptor LGR7 (RXFP1) is regulated by estrogen. . Ann N Y Acad Sci 2009; 1160:91-92.

27. Wang W, Hayami T, Kapila S. Female hormone receptors are differentially expressed in mouse fibrocartilages. Osteoarthritis and cartilage / OARS, Osteoarthritis Research Society 2009; 17(5):646-654

28. Faryniarz D, Bhargava M, Lajam C, Attia E, Hannafin J. Quantitation of estrogen receptors and relaxin binding in human anterior cruciate ligament fibroblasts. In Vitro CellDevBiol-Animal 2006; 42(7):176-181.

29. Dragoo JL, Lee RS, Benhaim P, Finerman GA, Hame SL. Relaxin receptors in the human female anterior cruciate ligament. Am J Sports Med 2003; 31(4):577-584.

30. Sutton KM, Bullock JM. Anterior Cruciate Ligament Rupture: Differences Between Males and Females. Journal of the American Academy of Orthopaedic Surgeons 2013; 21(1):41-50.

31. Hansen M, Couppe C, Hansen CSE, Skovgaard D, Kovanen V, Larsen JO, Aagaard P, Magnusson SP, Kjaer M. Impact of oral contraceptive use and menstrual phases on patellar tendon morphology, biochemical composition and biomechanical properties in female athletes. Journal of Applied Physiology. 2013

32. Salleh N, Baines DL, Naftalin RJ, Milligan SR. The Hormonal Control of Uterine Luminal Fluid Secretion and Absorption. J Membrane Biol 2005; 206(1):17-28

33. Gholami K, Muniandy S, Salleh N. Differential expression of $\mathrm{Na}+/ \mathrm{H}+$-exchanger (NHE-1, 2, and 4) proteins and mRNA in rodent's uterus under sex steroid effect and at different phases of the oestrous cycle. Biomed Res Int. 2013; 2013:840121.

34. Espinosa-Raya J, Plata-Cruz N,Neri-Gomez T,Camacho-Arroyo I,Picazo O. Effects of short-term hormonal replacement on learning and on basal forebrain ChAT and TrkA content in ovariectomized rats. Brain Research 2011; 1375:77-84.

35. Porkka-Heiskanen T, Laakso M L,Stenberg D. The effect of testosterone on serum gonadotropins of castrated rats kept under different lighting conditions. Biol Reprod 1992; 46(6):1127-1129.

36. Spritzer MD, Daviau ED, Coneeny MK, Engelman SM, Prince WT, Rodriguez-Wisdom KN. Effects of testosterone on spatial learning and memory in adult male rats. Hormones and Behavior 2011; 59(4):484-496.

37. Davis S, Tran J. What Are "Normal" Testosterone Levels for Women? Journal of Clinical Endocrinology \& Metabolism 2001; 86(4):1842-1843.

38. Wong ML, Medrano JF. Real-time PCR for mRNA quantitation. Biotechniques 2005; 39:1-10.

39. Nornadiah M, Yap BW. Power comparisons of Shapiro-Wilk, Kolmogorov-Smirnov, Liliefors and Anderson-Darling tests. Journal of Statistical Modelling and Analytics 2011; 2(1):22-33.

40. Becker GJ, Hewitson TD. Relaxin and renal fibrosis. Kidney Int 2001; 59(3):1184-1185.

41. MacLennan A. Relaxin--a review. Aust N Z I Obstet Gynaecol 1981; 21(4):195-202.

42. Dragoo JL, Castillo TN, Braun HJ, Ridley BA, Kennedy AC, Golish SR. Prospective Correlation Between Serum Relaxin Concentration and Anterior Cruciate Ligament Tears Among Elite Collegiate Female Athletes. American Journal of Sports Medicine 2011; 39(10):2175-2180.

43. Dragoo JL, Padrez K, Workman R, Lindsey DP. The effect of relaxin on the female anterior cruciate ligament: Analysis of mechanical properties in an animal model. The Knee 2009; 16(1):69-72.

44. Pearson SJ, Burgess KE, Onambélé GL. Serum relaxin levels affect the in vivo properties of some but not all tendons in normally menstruating young women. Experimental Physiology 2011; 96(7):681-688.

45. Fénichel P, Grimaldi M, Gillet J-Y, Olivero J-F, Harter M. Predictive value of hormonal profiles before stimulation for in vitro fertilization. Fertil Steril. 1989; 51:845-854.

46. Walf AA, Koonce C, Manley K, Frye CA. Proestrous compared to diestrous wildtype, but not estrogen receptor beta knockout, mice have better performance in the spontaneous alternation and object recognition tasks and reduced anxiety-like behavior in the elevated plus and mirror maze. Behav Brain Res 2009; 196(2):254-260.

47. Shultz SJ, Levine BJ, Nguyen AD, Kim H, Montgomery MM and Perrin DH. A comparison of cyclic variations in anterior knee laxity, genu recurvatum, and general joint laxity across the menstrual cycle. . Journal of orthopaedic research 2010; 28:1411-1417

48. Romani W, Patrie J, Curl LA, and Flaws JA. The correlations between estradiol, estrone, estriol, progesterone, and sex hormone-binding globulin and anterior cruciate ligament stiffness in healthy, active females. J Womens Health 2003; $12: 287-298$

49. Park SK, Stefanyshyn DJ, Ramage B, Hart DA, Ronsky JL. Relationship between knee joint laxity and knee joint mechanics during the menstrual cycle. Br J Sports Med 2009; 43(3):174-179.

50. Wojtys EM, Huston LJ,Boynton MD,Spindler KP,Lindenfeld TN. The Effect of the Menstrual Cycle on Anterior Cruciate Ligament Injuries in Women as Determined by Hormone Levels. Am J Sports Med 2002; 30(2):182-188.

51. Dhont M. History of oral contraception. The European Journal of Contraception and Reproductive Health Care 2010;15(S2):S12-S18.

52. Frankovich RJ, Lebrun C. Menstrual cycle, contraception, and performance. Clin Sports Med 2000; 19(2):251-271. 
53. Hicks-Little CA, Thatcher JR, Hauth JM, Goldfuss AJ, Cordova ML. Menstrual cycle stage and oral contraceptive effects on anterior tibial displacement in collegiate female athletes. J Sports Med Phys Fitness 2007; 47(2):255-260.

54. Cammarata ML, Dhaher YY. The differential effects of gender, anthropometry, and prior hormonal state on frontal plane knee joint stiffness. Clinical biomechanics (Bristol, Avon) 2008; 23(7):937-945.

55. Martineau PA, Al-Jassir F, Lenczner E, Burman ML. Effect of the oral contraceptive pill on ligamentous laxity. Clin J Sport Med 2004; 14(5):281-286.

56. Agel J, Bershadsky B, Arendt EA. Hormonal therapy: ACL and ankle injury. Medicine and Science in Sports and Exercise 2006; 38(1):7-12.

57. Dragoo JL, Korotkova TA, Kennedy AC, Kim HJ, Stewart DR. Trends in serum relaxin concentration among elite collegiate female athletes. Int J Womens Health 2011; 19(3):19-24.

58. Winn RJ, Baker MD, Merle CA,Sherwood OD. Individual and combined effects of relaxin, estrogen, and progesterone in ovariectomized gilts. II. Effects on mammary development. Endocrinology 1994; 135(3):1250-1255.

59. Shultz S, Gansneder BM, Sander TC, Kirk SE, Perrin DH. Absolute serum hormone levels predict the magnitude of change in anterior knee laxity across the menstrual cycle. J Orthop Res 2006; 24(2):124-131.

60. Lovering RM, Romani WA. Effect of testosterone on the female anterior cruciate ligament. American Journal of Physiology - Regulatory, Integrative and Comparative Physiology 2005; 289(1):R15-R22.

61. Shultz SJ, Kirk SE, Johnson ML, Sander TC, Perrin DH. Relationship between Sex Hormones and Anterior Knee Laxity across the Menstrual Cycle. Medicine \& Science in Sports \& Exercise 2004; 36(7):1165-1174.

62. O'Leary CB, Lehman C, Koltun K, Smith-Ryan A, Hackney AC. Response of testosterone to prolonged aerobic exercise during different phases of the menstrual cycle. European journal of applied physiology 2013; 113(9):2419-2424.

63. Bhasin S, Storer TW, Berman N, Callegari C, Clevenger B, Phillips J, Bunnell TJ, Tricker R, Shirazi A, Casaburi R. The effects of supraphysiologic doses of testosterone on muscle size and strength in normal men. N Engl J Med 1996; 335(1):1-7. 